\title{
Pretrial on SP3 Corruption Case in the Perspective of Victim Justice
}

\author{
Hery Firmansyah ${ }^{1 *}$, Eriyantouw Wahid ${ }^{2}$, Amad Sudiro ${ }^{3}$ \\ ${ }^{1}$ Lecturer at the Faculty of Law, Tarumanagara University, West Jakarta, Indonesia \\ ${ }^{2}$ Lecturer at the Faculty of Law, Trisakti University, West Jakarta, Indonesia \\ ${ }^{3}$ Lecturer at the Faculty of Law, Tarumanagara University, West Jakarta, Indonesia
}

Received: 26/06/2020

Accepted: 11/09/2020

Published: 20/12/2020

\begin{abstract}
Corruption in Indonesia has spread like a virus since the 1960s that is harming the nation's economy as well as victims of these crimes. Although the government tried to eradicate such crimes i.e. law enforcement, the issue still exists. The normative legal research method is used in the current study. The statute approach is utilized to review the termination of investigations as the basis for pre-trial submission by third parties for which data was collected by library research. To analyse the data, researchers examined the obtained materials to process it further. Results state that there is still a significant gap between law enforcement officials and people suffering from these corruption cases. The pre-trial complaint mechanism is not effective so far thus leaving ambiguity in victims' minds. Based on study results, we, therefore, recommend that some serious and clear eradication mechanism should be introduced by law enforcement agencies to reduce corruption in Indonesia as well as victims should be given special consideration in the whole justice process.
\end{abstract}

Keywords: Corruption, Criminal justice system, Criminal law, Pretrial, SP3

\section{Introduction}

Indonesia is a country that has prospered since the first day of independence with the greatest hope of society to have a just and prosperous country. Therefore, the Indonesian nation must protect its entirety in a great way, such as protecting the Indonesian nation and all Indonesian bloodshed, as well as advancing general prosperity, smartening the life of the nation, and participating in the world order.

However, if traced back, Indonesia still goes a long way toward achieving its own goals. One of the things that can be seen is where the legal norms upheld in this country are far from perfect to implement. Sudikno Mertokusumo defines the rule as a law that determines how people should behave, behave to protect their interests and the interests of others, or in another sense, legal norms are a concrete form of regulation [1]. As in the phenomenon of corruption crimes that are growing in Indonesia, this is what that harms many parties, ranging from the economic stability of the country to the people harmed by the perpetrators of corruption crimes, the state is forced to become a victim of such acts.

The issue of corruption seems to be always spoken by various circles. Although efforts to reduce such crimes have been vigorously implemented by the government, the problem has not been resolved yet [2]. The problem of corruption [3] is not only a problem faced by a nation or a state, but corruption is a problem faced by mankind because the impact of this crime is extraordinary $[4,5]$. Not only are the disadvantages of the economic aspect, but almost all aspects of life are influenced including social, cultural, political, and security [6].

Indonesia's commitment to eradicate corruption is demonstrated by the ratified United Nations Convention Against Corruption (UNCAC) with Law No. 7 of 2006, in addition to Law No. 20 of 2001 on Changes to Law No. 31 of 1999 on the Eradication of Corruption Crimes. As a criminal offense classified as an extraordinary crime, law enforcement has also used extraordinary means, such as the establishment of the Corruption Eradication Commission (KPK). Marwan Effendy conducted research quoted from the World Bank, stating Corruption is An Abuse of Public Power for Private Gains or could be referred to as an abuse of authority for personal gain [7].

Eradication of corruption is one of the means to create a healthy and authoritative governance climate to create a climate of people's lives that are comfortable, safe, protected, and have legal certainty. The eradication of corruption is not the goal, but rather the means (tools) to achieve that goal [8]. In line with this, there needs to be law enforcement in the eradication of corruption that is carried out as a preventive and repressive effort [9].

Related to the discussion proposed pretrial of corruption crimes, that pretrial aims to uphold and provide protection of human rights of suspects /defendants in the examination of investigations and prosecutions. This is related to the discussion proposed pretrial of corruption crimes, that pretrial aims to uphold and provide protection of human rights of suspects /defendants in the examination of investigations and prosecutions. This mechanism is seen as a form of horizontal surveillance of the rights of suspects/defendants in preliminary examinations.

The reasons for granting the authority to stop the

Corresponding author: Hery Firmansyah, Lecturer at the Faculty of Law, Tarumanagara University, West Jakarta, Indonesia. E-mail: heryf@fh.untar.ac.id 
investigation of these investigators are: to uphold the principles of a swift, precise and light-hearted judiciary, and at the same time to establish legal certainty in people's lives. If the investigator concludes that based on the results of the investigation, there is not enough evidence or reason to prosecute the suspect in advance of the trial, for what protracted handling and examining the suspect. It is better for the investigator to formally declare the termination of the investigation, to immediately create legal certainty. Pretrial as part of the prevailing criminal justice system in Indonesia is an effort to combat penal crimes by using criminal law as the main means of material criminal law as well as formal criminal law. It is the nature of the purpose of the law, one of which is to talk about justice. Justice is one of the purposes of every legal system among other purposes, namely legal certainty and benefit. This writing focuses on the pretrial of SP3 in corruption crimes and the perspective of pre-trial victims of corruption crimes which will be described normatively with the main source being legal material. The review of this legal material focuses on normative rules as well as pre-trial rulings against SP3.

Pretrial should not always be interpreted dogmatically as an order to follow the sound of the constitution, but more than that, it should pay attention to the social facts that occur in society, because legal certainty does not always reflect justice, justice is desirable not only in the conceptual but must touch feelings for everyone seeking justice or substantive justice.

\section{Methods}

\subsection{Approach to the problem}

In this study, the Authors used normative legal research methods, according to Soerjono Soekanto normative legal research, conducted by researching library materials or secondary data that include: Research on legal principles; Research into legal systematics; Research on vertical and horizontal synchronization levels; Legal comparison; Legal history [10]. In the writing of this dissertation, the main focus is research on the principles of the law [11], which reviewed the tangents of norms in kuhap and corruption crime law with norms derived from the study of philosophy and theory of law. So found fundamental problems and solutions. Normative legal research uses secondary data, with coverage of primary legal materials, secondary legal materials, and tertiary legal materials. The approach used is legal. The statute approach is used to review the termination of investigations as the basis for pretrial submissions by third parties based on corruption eradication laws, which govern specifically the judicial process and KUHAP.

\subsection{Nature of Research}

In terms of the nature of research, authors are more likely to use reform-oriented research types, which Hitchinson says intensively evaluates the adequacy of existing rules and which recommend changes to any rules found wanting [12]. The nature of the research that the authors use is a descriptive legal study in the form of exposure and aims to obtain a complete picture of the state of the law.

\subsection{Data Collection Methods}

As is the feature of normative legal research, the method of data collection can be done by library research, namely by researching library materials such as legislation, KUHAP, other laws related to Pre-trial, Jurisprudence, seminar results, scientific works in the form of literature and research results, journals, legal dictionaries and other manuals that provide clarity to this research.

\subsection{Data Analysis}

Activities carried out in the analysis of normative legal research data utilizing data obtained, analysed descriptively qualitatively i.e. analysis of data that cannot be calculated. The legal materials obtained are then discussed, examined, and grouped into certain sections to be processed into information data. The results of the analysis of legal materials will be interpreted using (a) systematic methods; (b) grammatical; and (c) teleological. The selection of systematic interpretations is intended to deceive the legal structure in this study. Systematic interpretation (systematische interpretation, dogmatische interpretation) is to interpret other legal texts.

\section{Results}

\subsection{Pre-trial against SP3 in Corruption Crimes}

The issue of corruption is a problem that can never be solved, the position of corruptors who are good at exploiting the situation of existing legal loopholes. Either in terms of rules that have not reached the behaviour of these corruption crimes or internal factors of law enforcement that is not maximal in conducting law enforcement. Good law enforcement should still refer to the existing rule of law and reflect the value of community justice. One of the legal efforts that can be made by the public as victims is to submit a pre-trial legal action against a corruption case that never gets certainty about the ongoing legal process both handled by the KPK, prosecutors, and the police.

The debate over the importance of pretrial submissions in SP3 cases that were not issued, but the case has not been processed by law for many years, opens up the potential for the case to lose the right to be prosecuted before the law. The legal loophole stipulated in the KUHAP arrangement makes many question marks as to whether it is permissible to file a legal action beyond the one stipulated by KUHAP. In practice, many corruption cases are found that are not processed but still are not issued SP3 by law enforcement. The limitations that people have in accessing and putting pressure on law enforcement officials to be serious in processing the law of a corruption case is a mandate of the law. It is not uncommon when submitted to the pretrial, the main difficulty is to open the veil related to the true extent that the legal process is underway in law enforcement because being processed by law and in the interests of the investigation does not make the public feel doubtful about the eradication of corruption that is underway. So, there needs to be a special study that looks at the perspective of SP3 conducted by third parties concerned in the case of corruption crimes to become a horizontal control of the law enforcement of corruption crimes through pretrial legal efforts. Pretrial as a complaint mechanism to date has not been effective. This is in stark contrast to the spirit of pretrial protection of human rights, something that never materialized during the Het Herziene Inlandsch Reglement (HIR).

\section{Discussion}

\subsection{Pre-trial against SP3 in corruption crimes}

The development of corruption in Indonesia is still high, while the eradication is still very slow, Romli Atmasasmita, stated that Corruption in Indonesia is already a flu virus that has spread throughout the governing body since the 1960s. Its eradication measures are still stalled today [13]. He further said that corruption is related to power because with that power the ruler can abuse his power for the benefit of his personal, family, and cronies. Corruption is considered an exceptional crime or 
"extraordinary crime", so it is often regarded as "beyond the law" because it involves high-level economic and high-level bureaucrats, both economic and government bureaucrats. Just imagine, the crime of corruption involving this power is very difficult to prove, besides that the will of the eradication of this act is manifestly hit with the interests of power that are very likely to involve the bureaucracy, as a result, it can already be predicted that this corruption seems to be "beyond the law" and as a form of "untouchable by the law" action [14]. This can certainly illustrate to all of us how easy it is to handle and prove a corruption case. Efforts to eradicate corruption have been underway since Indonesia's independence.

The flourishing of corruption in Indonesia certainly needs to be done very serious countermeasures through criminal politics either through penal efforts that are tackling after the sanction (repressive), non-penal efforts that prevent crime (preventative), or a combination of the two. It is worth remembering that now corruption is not just an extraordinary crime or an "extraordinary crime", but rather corruption has now become a humanitarian crime or a "crime against humanity" [15].

Law enforcement to eradicate conventional corruption crimes has so far proven to be a variety of obstacles. Public perception of prosecutors and police and or government agencies is seen as not functioning effectively and efficiently in the handling of corruption cases so that the public has lost trust. Besides, corruption has been shown to have harmed the country's finances, the country's economy, and hampered national development [16].

The process of handling corruption crimes has so far been carried out with a special event law in the Corruption Crimes Act, which is different from the law of events in the general judiciary. With the nature of corruption as an extraordinary crime (extraordinary crime) then the handling has done extraordinary (extraordinary measures) anyway.

The issue of corruption is an issue that can never be solved, the implementation of good laws must still refer to the existing rule of law and reflect the value of community justice. One of the legal efforts that can be made by the public as victims in the case of corruption crimes is to file a pre-trial legal action against a corruption case that does not get certainty against the legal process that goes well.

The purpose of the Pre-trial is to protect human rights against arbitrariness in the investigation process. With this pre-trial institution, any action that undermines human rights, let alone related to corruption crimes, is subject to strict supervision, both vertically and horizontally from other law enforcement agencies and interested third parties.

With the presence of the pre-trial institution it aims to carry out the mandate and principles contained in KUHAP that uphold human rights. And the implied purpose of pre-trial is stipulated in Article 80 of the KUHAP which is to uphold the law, the fairness of truth through horizontal supervision. The horizontal oversight here is to monitor the actions taken by investigators or prosecutors against suspects. Such actions must be carried out following the provisions of the law, carried out professionally and not in contravention of the law as stipulated in KUHAP. This is to minimize abuse of power in the implementation of law enforcement processes [17].

In the context of pre-trial submissions based on material SP3 filings, mainly due to the absence of a period of investigation sometimes makes the investigation process so long that there are de facto concerns that the investigation has been discontinued but the investigator has not issued a Termination Warrant (SP3). This prompted the Indonesian Anti-Corruption Society (MAKI) to file for pre-trial. One of them is to find out if one thing is still being investigated or has even been discontinued. Pre-trial institutions with submissions based on SP3 material is a form of respect for human rights, especially victims of corruption crimes in the eyes of the law. In its implementation law enforcement is far from the sense of justice expected by the community. The public judges that the state has not been able to guarantee justice and legal certainty evenly to all its citizens, because there is still a cut in the crackdown on perpetrators, especially corruption.

The dilemma of filing SP3 material has very much clashed with formal legalistic, as well as the way law enforcement officers are still resistant to public reports or community participation represented by third parties concerned about the criminality of corruption. This is evident from what the Boyamin Saiman said, that the clash between legal certainty and legal procedures must be carried out, often the evidence used that the law enforcement officer did not issue SP3. Even in the early days of the pre-trial submission SP3 material is not uncommon to pre-trial applicants that encourage that there is clarity on a corruption case, such as legal standing that must be fulfilled as an applicant, has no interest, has not been regulated by law, related to the rights of the public.

Regarding the submission of pre-trial by the NGO Masyarakat Anti-Corruption Indonesia (MAKI) shows the participation of the community in the eradication of corruption. Law No. 31 of 1999 on the Eradication of Corruption Crimes regulates specifically the participation of the community in CHAPTER V Article 41 and Article 42, that the community is given the opportunity by this law to participate, as for the form of participation in the prevention of corruption crimes, especially in developing preventive and supervisory measures that advance "a culture of accountability and transparency" or culture of accountability and openness [18]. This is strengthened by Government Regulation No. 43 of 2018 on Procedures for The Implementation of Community Participation and Awarding in the Prevention and Eradication of Corruption Crimes, which was ratified on September 17, 2018. In this, rules are regulated regarding the award to the people who have reported about the corruption, like the government will reward the whistle-blower with a maximum amount of 200 million rupiah (Rp) [19].

Pre-trial that has been submitted by MAKI NonGovernmental Organization is one of the reasons to find out if one case is still being investigated or has even been suspended investigation with the absence of SP3 material. The pre-trial submission that has been made by MAKI is a form of respect for human rights, especially victims of corruption crimes in the eyes of the law. This is in line with The Opinion of Komariah Emong Sapardjaja which states that in criminal law, the guarantee of human rights should be reflected in the law of his criminal proceedings [20]. Criminal proceedings should not be seen as laws that solely relate to criminals and criminal offenders only, but should also be seen as laws that guarantee the independence of citizens [21].

Respect for human rights has not been fully fulfilled both in KUHAP and in corruption crimes. The lack of attention to victim protection in KUHAP is also one of KUHAP's current weaknesses, which is considered a masterpiece of the Indonesian nation. The position of victims in the criminal justice system as well as in judicial practice is relatively poorly regarded because the provisions of Indonesian law still rest on protection for offender oriented. Whereas, from a criminological and criminal law view crime is a conflict between individuals that inflicts harm on victims, communities, and offenders themselves where of the three groups the interests of victims of crime are a major part of the crime where 
according to Andrew Ashworth, "primary an offense against the victim and only secondarily an offense against the wider community or state" [22].

The law has made obstructive restrictions a basis for investigators to stop an investigation. This limited restriction to avoid the possibility of termination of the investigation that arises due to the subjectivity of the investigator of a criminal event, thus such subjectivity is still possible. In the case of SP3 material against the basis of submission outside the provisions of Article 109 (2) KUHAP, then the way the pre-trial judge works is to do the method of legal discovery. In this case the Judge has an important position in the legal system, because the judge has a function that essentially complements the provisions of the written law through rechtvinding (discovery of the law) which leads to the creation of new law. The function of the discovery of the law must be interpreted to fill the recht vacuum and prevent the mishandling of a case on the grounds that the law is unclear or it does not exist [23].

In the investigator's notes for several pre-trial cases based on SP3 material worth scrutiny is, the view of the judge that the actions and attitudes of law enforcement officers who do not immediately bestow the case file are one form of horizontal control to the performance of law enforcement officers:

\subsubsection{Tanjung karang district court ruling number 01/pid/pra/2008/pn.tk}

Important things to note in the judge's deliberations here are: 1) that with the attitude, treatment, and actions of the Respondent let the case of suspect Simon Susilo and the suspect Aman Susilo protracted and has exceeded the grace period long enough, when according to the respondent's confession in the answer that the examination conducted by the investigator (Police) has been optimal and has received the submission of the suspect along with will conduct an additional examination and it turns out that from the facts revealed in the trial as considered above, it turns out that the additional examination intended by the respondent as intended by the respondent cannot be proven.

2) Based on the above considerations, according to the District Court that although the Respondent has not issued a termination letter of prosecution on behalf of the suspect Simon Susilo and the suspect Aman Susilo. However, with the attitude, treatment, and actions of the respondent as considered above, the case file on behalf of suspect Simon Susilo and suspect Aman Susilo to Tanjung Karang District Court for trial can be categorized or likened to the act of "Termination of Prosecution" and therefore the actions of the Respondent shall be declared invalid.

\subsubsection{Central Jakarta district court ruling number 04/pid.prap/2010/pn.jkt.pst}

The judge who examines the pre-trial application case argues that the Central Jakarta District Court is authorized to examine and adjudicate the applicant's pre-trial application. In the evidence of criminal law sought is material truth, so the precedence is the substance of whether the right respondent I (Government of the Republic of Indonesia, President of the Republic of Indonesia, and Attorney General of the Republic of Indonesia) has conducted a secret termination of prosecution then the benchmark is the propriety. So this becomes a guideline in the action of law enforcement officers on the matters he handled.

\subsubsection{Boyolali district court ruling number 01/pra/2014/pn.byl}

That in Article 109 paragraph (2) KUHAP has authorized the investigator to be able to stop the investigation based on the following reasons:
1 There is not enough evidence

2 The incident turned out not to be a criminal offense;

3 The investigation is discontinued for the sake of the law.

With the termination of the investigation, the investigator must inform the public prosecutor, the suspect, or his family. In other words, the SP3 issuer is an obligation and if it is not done, then the process will certainly suffer a formal defect.

\subsubsection{Banjarnegara district court ruling number 1 / pid pra / 2017 / pn bnr.}

That in Article 109 paragraph (2) of KUHAP, it is stipulated that if the investigator stops the investigation, it is mandatory to let know the public prosecutor and the suspect or his family. However, in practice, Investigators rarely issue Notices of Termination of Investigation (SP3) on the grounds of fear that the victim/whistle-blower will conduct a pre-trial. As a result, it is not uncommon for investigators to silence cases until the case cannot be processed because of the prosecution as stipulated in Article 78-80 of the Criminal Court. Even if the investigators file a case, there is an unfinished back-and-forth between the investigator and the prosecutor, because the investigator is not carrying out the instructions given by the prosecutor so that the file can be declared as the basis for drafting the indictment. That to overcome different perceptions even interpretations need to be carried out intense coordination measures between investigators and the Public Prosecutor. The spirit and willingness to coordinate will create a good relationship and gain one view in the case and will eliminate selfish values in carrying out the process of law enforcement. So, in turn, it will get a better outcome than the earlier process. KUHAP itself does not limit the number of times prosecutors can return files. Although being aware of the back-and-forth of the files, reduces the efficiency of the investigation and makes the handling of the case protracted, which can create legal uncertainty in a case. The uncertainty of the legal process can cause disquiet for both the report and the suspect. If the case is doable, it should be processed according to the provisions otherwise, it is ideally discontinued, to create legal certainty. Second, however, investigators can ask a joint title of the case, to equate perception in the context of the Integrated Criminal Justice System. Third, if the investigator has been unable to develop the investigation, then the investigator stated that the investigation is optimal.

\subsubsection{South Jakarta district court ruling number 24/pid/pra/2018/pn.jkt.sel.}

Because there are no standard guidelines in KUHAP and prone to irregularities in its implementation, then some judges make inroads by interpreting the actions of investigators categorized as a form of termination of investigation as referred to in the phrase "termination of investigation" in KUHAP. From the facts obtained as mentioned above, there has been sufficient preliminary evidence about alleged corruption offenses in the form of abuse of authority in the granting of FPJP and The Determination of Bank Century as a Bank to fail to have a systemic impact by Bank Indonesia Officials namely Siti Ch. Fadjriah, Budi Mulya........which can inflict financial losses of the State that can be suspected to have violated Article 3 of Law No. 31 of 1999 Eradication of Corruption Crimes jo. Article 55 paragraph (1) to -1 jo. Article 64 paragraph (1) of the Pent-Up" and the report is also known to WARIH SADONO as Deputy for The Field of Suppression in the KPK; In this case, the judge is very observant and wise in considering the legal challenges proposed by the parties. The Pre-trial judge disagreed with the Applicant that the KPK had materially suspended the investigation, but in the interests of law and 
justice and protection of human rights, the KPK should continue to thoroughly investigate and prosecute the cases mentioned in the indictment of Budi Mulya, whatever the risks because that is the logical consequence that the KPK must bear to the public. In some of these rulings, related to the nature of the pre-trial verdict Number 01/Pid.Prap/2008/PN. TNK, 04/Pid.Prap/2010/PN.Jkt.Pst, 0101/Pid.Prap/2014/PN. Byl, /PID. Prap/2017/PN.Bjn, 24/Pid.Prap/2018/PN.Jkt.Pst is final and binding. This is as stated in Article 83 of KUHAP [24], which then becomes a juridical answer to investigators to act on the warning of the judge's ruling as a law.

Based on the above description, it is precisely said that the pre-trial institution used as a form of horizontal control of law enforcement to work under the law and not apply arbitrarily, because another important issue in the application of SP3 material is related to minimal public information, many things in the legal press subjectivity of the dominant investigator and prosecutor, so sp3 this material is akhrinya as a step to correct the matter.

\subsection{Victim's perspective on corruption crimes}

Speaking of victims of crime at first, it is certainly the victim of an individual or individual himself; this view is not wrong for the common good in society. For example murder, persecution, theft, and so on. In the view of Criminal Law Science the notion of "victim of crime" is the terminology of Criminology and Victimology [25] and was later developed in the criminal law and/or criminal justice system. The logical consequence of victim protection in the 1985 UN Congress in Milan (on "The Prevention of Crime and the Treatment of Offenders") suggests that victims' rights should be seen as an integral aspect of the total criminal justice system ("victims' rights should be perceived as an integral aspect of the total criminal justice system"). With the social construction of the law itself, all crimes have victims. In fact, an act is defined as a crime because a person or something is seen as a victim. In this sense, victimization-which is the conception of the victimprecedes the definition of the act as criminal. Victims cannot be imagined, that criminal law is made not enforced. A victimless crime can only be one of the facts defined by outside observers (by the social construction of law itself, all crimes have a victim. Acts are defined as criminal because someone or something is conceived of as a victim. In this sense, the victimthat is a conception of the victim- precedes the definition of an act as criminal. If a victim cannot be imagined, criminal law is nether created not enforced. A victimless crime can only be one that is defined after the fact by an outside observer) [26].

Theoretically and in practice in the Indonesian Criminal Justice System the interests of victims of crime are represented by the Public Prosecutor as part of the protection of society following the theory of social contract argument and social solidarity theory (social solidary argument) [27]. In general, in the theory there are two models of protection, namely: First, the procedural rights model or in France called the partie civile model (civil action system). This model emphasizes the possible role of victims in criminal justice processes such as assisting prosecutors, being involved in every level of judicial examination, must be heard if the convicted is released on parole, and so on. Also, by actively participating in the criminal justice process, the victim can regain her self-esteem and confidence. However, with the involvement of victims has a positive facet in law enforcement, and has a negative facet because the active participation of victims in the implementation of criminal justice processes can cause personal interest to lie above the public interest. Victims who are interested in criminal cases that have caused harm to him are terminated due process will also be suspended his right to justice. Article 80 KUHAP only accommodates the application to check the validity or not the termination of the investigation or prosecution, so in this case the more interested are the victims. Victims of crime can perform the role and function of horizontal supervision of the implementation of the criminal justice system to uphold law, justice, and truth. Supervision is carried out by the victim as an interested party in the form of a request for examination about the legitimacy or not termination of the investigation and prosecution through the pre-trial institution [28]

The process of resolving criminal cases through criminal justice is interesting when viewed from the perspective of the victim as the party that suffers the most losses. It is unfortunate that in the criminal justice process victims are not actively involved. Criminal justice prosecutes perpetrators for allegedly violating criminal law, not violations of the rights of victims, although it is the victims who suffer the most harm. As stated at the beginning of this section of the paper, that in the early stages of the process of resolving cases through criminal justice, victims of crime have great and decisive authority but at the next stage, that authority becomes lost, while the authority of the police and prosecutors strengthens. The loss of the victim's authority in the criminal justice settlement process will invite a lot of problems, especially about the roles of police, prosecutors, and judges as well as the mechanism of settlement of criminal cases through criminal justice according to the view of the victims of crime.

The legal conceit that will arise if no proper formulation of SP3 material or SP3 is secretly issued by the investigator is that the case will lose the right to be prosecuted in advance of the law, and will return to the provisions of daluarsa in Article 78 of the Criminal Code. Regarding the prosecution provision stipulated in Article 78 paragraph (1) of the Penal Code, which states that the authority to prosecute criminals is removed due to expiry: about all violations and crimes committed by printing after one year; crimes threatened with a fine, imprisonment, or imprisonment of at least three years, after six years; about crimes threatened with a prison sentence of more than three years, after twelve years; crimes threatened with the death penalty or life imprisonment, after eighteen years [29].

Against the actions of investigators who do not follow up on a criminal case that has been reported to the authorities, then the Whistle-blower or Victim of a Crime, or Suspect, pursues a legal path by submitting a request for examination through the Pre-trial Institution, i.e. to conduct a test against the legitimate or not a termination of the investigation. Although there is an application received or granted by the Judge of the Pre-trial Institution with legal consideration, that even if, the fact of the trial there is no Termination of Investigation Warrant (SP3) in the investigation process, but on the other hand, there is also a test application for the termination of the investigation which is rejected with the consideration of the law that for the actions of the investigator who does not follow up on a criminal case, as long as it is not issued or issued an Investigation Termination Warrant (SP3), does not include the termination of the investigation and therefore, is not the object of the Pre-trial, so the Pre-trial Judge rejects the Pre-trial Application submitted by the Pre-trial Applicant.

Moreover, in KUHAP that applies in Indonesia, it does not contain provisions regarding the understanding of the termination of the investigation, resulting in different interpretations related to the termination of the investigation. The fact of this law, increasingly shows that there has been a legal blurring of Article 77 KUHAP related to the authority of the Pre-trial Institution to test the validity of the termination of 
the investigation as one of the objects or scope of the Pre-trial as stipulated in the applicable Criminal Code in Indonesia, and with the rejection of the Pre-trial Application for a termination of the investigation in the absence of follow-up and clarity from the Investigator, with legal consideration due to the absence of formality of the Termination of Investigation Warrant (SP3) issued by the Investigator and notified to the Whistleblower or Victims of Criminal Acts or Suspects, precisely resulting in the criminal case not also getting follow-up and protracted until an indefinable time limit, thus indicating that the Pretrial Institution has not been able to provide legal protection, either for the Whistleblower, The Victim of the Crime, or suspects whose criminal cases are not followed up at the level of investigation [30].

In looking at the issue of SP3 material or discreetly that has no rules in the current criminal proceedings' law, then, the author asks a mediator why then the evidence to propose the basis of SP3 material or the cessation of investigation in secret can seek the presence of a sense of justice for the community. The protection of victims of crime in carrying out legal efforts of its existence is very important considering that based on empiric studies it turns out that the victim's reaction to the court's ruling is judged incompatible with the sense of justice while from another dimension it turns out that the victim himself cannot do something to test the verdict because the existing law does not provide an opportunity to make legal efforts against the court's ruling. Departing from the above dimensions, there may be constraints manifested in the protection of victims through procedural rights [31].

The criminal justice system is a system in society to ward off crime, intending to prevent people from becoming victims of crime, resolving crimes that occur as the public is satisfied that justice has been upheld and the guilty convicted and trying those who have committed crimes not to repeat their crimes [32]. If we look at that from a justice perspective, then we can do that in the theory of dignified justice, who adheres to the principle that a legal practitioner cannot say that he works without inspiration from legal philosophy, legal theory, or doctrinal.

Some legal studies assert that victims and witnesses should get legal protection as a form of reward for their contribution to the judicial process, rather than simply being treated as a "tool" in the judicial process. The issue of crime always revolves around the question of what can be done to criminals and no one questions what can be done to the victim. Everyone thinks that the best way to help the victim is to catch the criminal. So far the victim has not received enough attention. With the taking of an action or crimes against the perpetrator, the problem against the victim is considered to have been resolved [33]. There is still an understanding that crime is a form of an attack on the state so that the crime is a conflict between the perpetrator and the victim.

The state protects citizens, so it is the country that is dealing with the perpetrators of the crime. This is where the position of the victim appears as the party that is the most harmed related to a crime of losing its role [34]. The terminology "the aggrieved party" refers to the victim, as set out in the explanation of the article. By incorporating civil proceedings into criminal proceedings, legislators intend to expedite procedures and cut the cost of litigation that is known to be high enough.

Termination of investigation or termination of prosecution harms victims who suffer as a result of a crime. In the case of corruption, the victims are the state and the community because in the finances of the state there are also sourced from the community such as taxes that will be returned to the community in the form of the construction of projects for the benefit and prosperity of the community.

From the above description, it can be said that it is not easy to realize substantial legal justice in law enforcement in Indonesia. The Pretrial Institution, which is expected to be the umbrella of the law so that there is no violation of the rights of a person or those caught up in litigation.It does not fully meet expectations, because there are still irregularities due to abuse of power or the use of legal loopholes. Victims of crime are the most suffering as a result of crime, instead not getting as much protection as the law provides to the perpetrators of the crime. As a result, by the time the perpetrator of the crime has been convicted by the court, the condition of the victim of such a crime is not cared for at all. Whereas the issue of justice and respect for human rights; applies not only to the perpetrators of crimes, but also victims of crime.

\section{Conclusions \\ 4.1 Pre-trial against sp3 in corruption crimes}

The debate over the importance of pretrial submissions in SP3 cases that were not issued but the case has not been processed by law for many years, opens up the potential for the case to lose the right to be prosecuted before the law. In practice, many corruption cases are found that are not processed but are not issued SP3 by law enforcement. The limitations that people have in accessing and putting pressure on law enforcement officials to be serious in processing the law of a corruption case is a mandate of the law. So there needs to be a special study that looks at the perspective of SP3 conducted by third parties concerned in the case of corruption crimes to become horizontal control of the law enforcement of corruption crimes through pre-trial legal efforts. The work of law enforcement officers in eradicating corruption needs to be supervised for actions taken under the law to boil down to community justice. The submission of SP3 material looks at the purpose of the Pretrial itself which is to protect human rights, based not only on the defendant but also on the victim's side, against the arbitrariness in the investigation process of the case.

With this pretrial institution, any action that undermines human rights, let alone related to corruption crimes, is subject to strict supervision, both vertically and horizontally from other law enforcement agencies and interested third parties. That the basis of SP3 is legal, should not be based on the subjectivity of law enforcement officers. The need for legal certainty in the investigation of a corruption case not only provides legal protection for the accused, but also to the victims of corruption to continue to push the legal process to other agencies so that no violator of the law who has committed corruption activities that loses the finances of the country is free from the deterrent of punishment (loss of the right to prosecution due to daluarsa, or loss of evidence or suspects fleeing). Public participation becomes inevitable in eradicating corruption in its capacity as a third party of interest in filing a material SP3 pretrial application (cases that are stopped silently or without clarity).

Law enforcement to eradicate corruption crimes committed so far has proven to be a variety of obstacles. Even today corruption has become an extraordinary crime so it must be dealt with extraordinary measures. The public's view of prosecutors and police and or government agencies is seen as not yet effective and efficient in its handling of corruption cases so that the public almost loses trust in law enforcement. The criminal justice system is essentially a criminal law enforcement process, while the purpose of Pretrial is to protect human rights against arbitrariness in the investigation process. With this pretrial institution, any action that undermines human 
rights related to corruption crimes, is subject to strict supervision, both vertically and horizontally from other law enforcement agencies and interested third parties. In the context of pretrial submissions based on material SP3 filings, mainly due to the absence of a period of investigation sometimes makes the investigation process so long that there are de facto concerns that the investigation has been discontinued but the investigator has not issued a Termination Warrant (SP3). This prompted the Indonesian Anti-Corruption Society (MAKI) NGO to file for pre-trial. One of them is to find out if one thing is still being investigated or has even been discontinued. Pretrial institutions with submissions based on SP3 material is a form of respect for human rights, especially victims of corruption crimes in the eyes of the law.

The dilemma of filing SP3 material is much bumped up with formal legalistic, as well as the perspective of law enforcement officers who are still resistant to community reports or community participation represented by third parties concerned about the criminality of corruption. Pre-trial that has been submitted by MAKI NGO one of the reasons is to find out if a case is still being investigated or has even been suspended investigation with the absence of SP3 material. The pretrial submission that has been made by MAKI is a form of respect for human rights, especially victims of corruption crimes in the eyes of the law. The lack of attention to victim protection in KUHAP is also one of KUHAP's weaknesses at this time. The position of victims in the criminal justice system as well as in judicial practice is relatively poorly regarded because the provisions of Indonesian law still rest on protection for offender oriented.

The function of horizontal supervision of the preliminary examination process conducted by the pretrial institution is part of the framework of the integrated criminal justice system. Public participation to correct or provide this feedback can evaluate the actions of law enforcement officers. In the case of SP3 material that is the basis of filing outside the provisions of Article 109 (2) OF KUHAP, then the way the pretrial judge works is to perform the method of finding hokum because the judge has a function that complements the provisions of the written law through rechtvinding (discovery of the law) that leads to the creation of new law.

The opportunity for a new legal effort based on the submission of SP3 material to reduce the release of legal deterrents against perpetrators of corruption should be based on clear rule of law, such as the new rule of law which contains time limits related to the investigation and prosecution of cases. So it can then be said that pretrial agencies are used as a form of horizontal control of law enforcement to work under the law and not to apply arbitrarily, due to other important issues in the filing of SP3 material.

\subsection{Pre-trial victim perspective in corruption crime}

The provisions in KUHAP contain human rights protections and formal-adjudicative that must go through various procedures or stages such as investigation, arrest, detention, search, seizure, pretrial, prosecution, examination at a court hearing (through regular or brief or quick examination), to the implementation of the court's ruling, as well as legal efforts based on the procedures specified in KUHAP. In the process of resolving the case through criminal justice, the victim of the crime has great authority and determines but at a later stage that authority becomes lost, while the authority of the police and prosecutors strengthens. The loss of the victim's authority in the criminal justice settlement process will invite a lot of problems, especially regarding the roles of police, prosecutors, and judges as well as the mechanism of settlement of criminal cases through criminal justice. According to the view of the victims of crime legal consequence that will arise if the discovery of the proper formulation of SP3 material or SP3 issued secretly by the investigator is that the case will lose the right to be prosecuted in advance of the law, and will return to the provisions of daluarsa in Article 78 of the Criminal Court. Against the actions of investigators who do not follow up on a criminal case that has been reported to the authorities, then the Whistleblower or Victim of a Crime, or Suspect, pursues a legal path by submitting a request for examination through the Pretrial Institution, i.e. to conduct a test against the legitimate or not a termination of the investigation.

There are several weaknesses in the pretrial institution, one of which is that there are many legal loopholes in the provisions of KUHAP where the practice relies heavily on the discretion of law enforcement officers. Pretrial is judged to be able to work when violations of the implementation of forced attempts have occurred (post factum), so it is more repressive than preventive. Efforts to combat and win resistance to corruption certainly cannot be done individually, but it needs the involvement of the wider public. To make sure justice for the parties who are litigation in court. In the case of pre-trial applications whose material is outside the provisions of Article 77 KUHAP is decided not granted and or rejected because the judge thinks conventionally, solely based on the provisions of KUHAP in a normative juridical perspective. The protection of victims of crime in carrying out legal efforts of its existence is very important considering that based on empiric studies it turns out that the victim's reaction to the court's ruling is judged incompatible with the sense of justice while from another dimension. It turns out that the victim himself cannot do something to test the verdict because the existing law does not provide an opportunity to make legal efforts against the court's ruling. Departing from the above dimensions, there may be constraints realized victim protection through procedural rights. Victims and witnesses should receive legal protection as a form of reward for their contribution to the judicial process, and not simply treated as a "tool" in the judicial process.

\section{Recommendations}

1. There need to be clear rules based on pretrial submissions based on the reason for the sp3 material as well as the arrangement of more assertive pretrial objects.

2. There needs to be a judge's independence, related to the pretrial on corruption matters.

3. That victims should be given special attention in the criminal justice system, taking into account the rights of victims in legal protection and regulated in the new KUHAP

\section{Ethical issue}

Authors are aware of, and comply with, best practice in publication ethics specifically about authorship (avoidance of guest authorship), dual submission, manipulation of figures, competing interests, and compliance with policies on research ethics. Authors adhere to publication requirements that submitted work is original and has not been published elsewhere in any language.

\section{Competing interests}

The authors declare that no conflict of interest would prejudice the impartiality of this scientific work.

\section{Authors' contribution}


All authors of this study have a complete contribution to data collection, data analyses, and manuscript writing.

\section{References}

1 Mertokusumo S. Hukum acara perdata Indonesia. Universitas Atma Jaya Yogyakarta; 2006.

2 Purnomo B. Potensi kejahatan korupsi di Indonesia. Bina Aksara; 1983.

3 Hamzah A. Perbandingan Pemberantasan Korupsi di Berbagai Negara. Sinar Grafika; 2004

4 Lubis, M., dan Scott, J.C., Korupsi Politik, Yayasan Obor Indonesia: Jakarta, 1993.

5 Sudarto. Hukum Dan Hukum Pidana. Bandung: Alumni, 1981.

6 Gosita A. Masalah korban kejahatan, PT. Bhuana Ilmu Populer Kelompok Gramedia, Jakarta. 2004

7 Effendy M. Sistem peradilan pidana: tinjauan terhadap beberapa perkembangan hukum pidana. Referensi; 2012.

8 Widjajanti E, Candra S. Pemikiran Romli Atmasasmita: Tentang Pemberantasan Korupsi di Indonesia.2016.

9 Departemen Kahakiman, Pemberantasan Tindak Pidana Korupsi : Pembentukan Undang-Undang Nomor 3 Tahun 1971 (Dirjen Pembinaan Hukum Departemen Kahakiman 1971).

10 Soekanto S, Mamudji S. Penelitian Hukum Normatif, cetakan ke13. Jakarta: Raja Grafindo Persada. 2011.

11 Soekanto S, Mamudji S. Penelitian hukum normatif: Suatu tinjauan singkat. RajaGrafindo Persada; 2001.

12 Muhammad A. Hukum dan Penelitian Hukum. Bandung: PT. Citra Aditya Bakti. 2004.

13 Atmasasmita R. Sekitar Masalah Korupsi: Aspek nasional dan aspek internasional. Mandar Maju; 2004.

14 Indriyanto SA. Korupsi Kebijakan Aparatur Negara \& Hukum Pidana, CV. Diadit Media, Jakarta. 2007.

15 Hatta M. Kebijakan politik kriminal: Penegakan hukum dalam rangka penanggulangan kejahatan. Pustaka Pelajar; 2010.

16 Butt S. The Function of Judicial Dissent in Indonesia's Constitutional Court. Constitutional Review. 2018 May 31;4(1):126. Available from: https://doi.org/10.31078/consrev411

17 Rahmanto, A. Comparative Study of The Authority of Pretrial Objects as an Effort to Reform the Law. (Case Study of Several Pretrial Applications Related to The Determination of Suspects in Pretrial Objects). Jurnal Mahasiswa S-2 Hukum Universitas Tanjungpura, 10.

18 Arief BN. Kapita selekta hukum pidana, Cetakan Ketiga. 2013.

19 Government Regulation No. 43 of 2018.

20 Sapardjaja, KE. The doctrine of the unlawful nature of Materiel in Criminal Law. Disertasi Universitas Padjajaran, Bandung. 1994.

21 Rukmini, SM. The Meaning and Setting of The Principle of Presumption of Innocence Relates to the Principle of Equality of Position in Law based on Article 27 Paragraph (1) of the 1945 Constitution of the Indonesian Criminal Justice System. Disertasi Bandung. 2001

22 Ashworth A. Victim impact statements and sentencing. Criminal Law Review. 1993 Jul 1:498-509.

23 Kusumaatmadja M. The concepts of Law in Development. Bandung: Alumni. 2002

24 Sahbani. A. Cabut Aturan Banding Praperadilan [Internet]. Hukum Online [updated 2012 May 1; cited March 10, 2020]. Available from:

https://www.hukumonline.com/berita/baca/lt4f9ff3cb4fbf8/mkcabut-aturan-banding-praperadilan.

25 Sutherland EH, Cressey DR, Luckenbill DF. Principles of criminology. New York: Lippincott Company. 1974

26 Drapkin I. Victimology. Lexington Books, DC Heath, and Company. 1975

27 Arief BN. Teori-Teori Dan Kebijakan Pidana, Alumni.

28 Mudzakir. Victims of Crime in The Perspective of Indonesian Criminal Justice. Postgraduate Program Thesis of The Faculty of the Law, University of Indonesia. 1992.

29 Hutomo, SH. Expiration of Prosecution in Corruption Crime [Internet]. Hukum Online [updated 2018 October 5; cited March 23, 2020]. Available from: https://www.hukumonline.com/klinik/detail/ulasan/lt58e921c313 b7b/daluwarsa-penuntutan-dalam-tindak-pidana-korupsi.
30 FS BR. Pengujian Sah Tidaknya Penghentian Penyidikan Melalui Lembaga Praperadilan. Kumpulan Jurnal Mahasiswa Fakultas Hukum. 2016 Aug 9.

31 Mulyadi L. Wajah sistem peradilan pidana anak Indonesia. Penerbit PT Alumni; 2014

32 Atmasasmita R. Sistem Peradilan Pidana (Criminal Justice System) Perspektif Eksistensialisme Dan Abolisionalisme. Bina Cipta, Jakarta. 1996.

33 Azisa N, Akub S, Kaim S, Heryani W. Compensation And Restitution for Victims of Crime As Implemnetization of The Principle of Justice. Postgraduate Program Dissertation of Hasanuddin University Makassar. 2015

34 Zulfa EA. Restorative Justice in Indonesia: Traditional Value. Indon. L. Rev.. 2011;1:33. Available from: http://dx.doi.org/10.15742/ilrev.v1n2.81 